\title{
Comparison of Anesthetic Efficacy of Intranasal Administration of Medetomidine / Ketamine and Diazepam / Ketamine Combinations on New Zealand White Rabbits
}

\author{
Zeynep BOZKAN ${ }^{1, a,{ }^{*}}$ Rahime YAYGINGUL ${ }^{1, b}$, Osman BULUT ${ }^{2, c}$
}

\author{
${ }^{1}$ Aydın Adnan Menderes University, Faculty of Veterinary Medicine, Department of Surgery, Aydın/TURKEY \\ ${ }^{2}$ Muğla Sıtkı Koçman University, Milas Faculty of Veterinary Medicine, Department of Surgery, Muğla/TURKEY \\ aORCID: 0000-0003-4233-6496, bORCID: 0000-0001-7402-9031, 'ORCID: 0000-0003-2773-8243, dORCID: , eORCID:
} \begin{abstract}
This study aimed to determine the anesthetic efficacy of intranasal medetomidine/ketamine and diazepam/ketamine combinations in New Zealand White rabbits. For this purpose, 12 adult New Zealand White rabbits weighing 2.3-4.1 kg were used by randomly dividing the animals into two groups of six animals: Medetomidine - Ketamine (MK) and Diazepam - Ketamine (DK). Intranasally, medetomidine $\left(0.2 \mathrm{mg} \mathrm{kg}^{-1}\right)$ and ketamine $\left(10 \mathrm{mg} \mathrm{kg}^{-1}\right)$ combination was administered to the MK group and, diazepam $\left(1 \mathrm{mg} \mathrm{kg}^{-1}\right)$ and ketamine $\left(10 \mathrm{mg} \mathrm{kg}^{-1}\right)$ to the DK group. Before and 5, 10, 15, $20,25,30,45$, and 60 minutes after anesthesia, loss, and recovery of the reflexes were evaluated. Onset and duration of the anesthesia, duration of the surgical anesthesia, and the total anesthesia time were also recorded. Loss and recovery time of reflexes was shorter in the DK group compared to the MK group. Respiratory rate, heart rate, and SpO2 decreased as expected in both groups but all parameters, especially SpO2, were lower in the MK group comparing the DK group. These results showed that both MK and DK combinations administered IN provide anesthesia in the time and depth that minor surgical procedures and clinical applications could be performed. Although it seems promising considering its practicality and anesthetic efficacy, it is clear that more detailed studies with more animals are needed before the safety of these protocols can be established.Their use, recommended for routine clinical procedures when considered $\mathrm{SpO} 2$, was severely decreased, especially in the MK group.
\end{abstract}

Keywords: Anesthesia, Intranasal, Ketamine, Rabbit, Sedation.

\section{Yeni Zelanda Beyaz Tavşanlarında Medetomidin / Ketamin ve Diazepam / Ketamin Kombinasyonlarının İntranazal Uygulamasının Anestezik Etkinliğinin Karşılaştırılması}

Özet: Bu çalışmada Yeni Zelanda Beyaz tavşanlarında intranazal medetomidin/ketamin ve diazepam/ketamin kombinasyonlarının anestezik etkinliğini belirlemek amaçlandı. Bu amaçla, 2,3-4,1 kg ağırlığında 12 adet yetişkin Yeni Zelanda Beyaz tavşanı Medetomidin - Ketamin (MK) ve Diazepam - Ketamin (DK) olmak üzere rastgele 6'şarlı iki gruba ayrılarak kullanıldı. Intranazal olarak, MK grubuna medetomidin $\left(0,2 \mathrm{mg} \mathrm{kg}^{-1}\right)$ ve ketamin $\left(10 \mathrm{mg} \mathrm{kg}^{-1}\right)$, DK grubuna diazepam $\left(1 \mathrm{mg} \mathrm{kg}^{-1}\right)$ ve ketamin $\left(10 \mathrm{mg} \mathrm{kg}^{-1}\right)$ kombinasyonu uygulandı. Anestezi öncesi ve anesteziden 5, 10, 15, 20, 25, 30,45 ve 60 dakika sonra reflekslerin kaybı ve geri kazanımı değerlendirildi. Anestezi başlangıcı ve süresi, cerrahi anestezi süresi ve toplam anestezi süresi de kaydedildi. DK grubunda refleks kaybı ve geri kazanım süresi MK grubuna göre daha kısaydı. Solunum hızı, kalp hızı ve SpO2 her iki grupta da beklendiği gibi azaldı ancak MK grubunda DK grubuna göre başta SpO2 olmak üzere tüm parametreler daha düşüktü. Bu sonuçlar, intranazal uygulanan hem MK hem de DK kombinasyonlarının, küçük cerrahi işlemlerin ve klinik uygulamaların yapılabileceği zaman ve derinlikte anestezi sağladığını göstermiştir. Pratikliği ve anestezik etkinliği göz önüne alındığında sonuçlar umut verici görünse de, özellikle MK grubunda SpO2'nin ciddi şekilde azaldığı düşünüldüğünde bu protokollerin güvenliğinin oluşturulabilmesi ve rutin klinik prosedürler için kullanımlarının önerilebilmesi için daha fazla hayvanla daha ayrıntılı çalışmalara ihtiyaç bulunmaktadır.

Anahtar Kelimeler: Anestezi, Intranazal, Ketamin, Sedasyon, Tavşan.

\section{Introduction}

Rabbits are widely considered companion animals as well as laboratory animals. During the applications that may cause pain or stress for diagnosis, treatment, or any research, the administration of anesthesia is essential to the animal's welfare (Carlsson et al., 2004; Weiland et al., 2017). Generally, anesthesia provides unconsciousness, stress, and pain management during diagnostic-therapeutic interventions such as radiography, wound care, endoscopy (Vesal and Zare, 2006).

Because rabbits are one of the most common animal species on which anesthetic applications are performed, it is vital to define safe anesthesia protocols (Brodbelt, 2009; Claire et al., 2005). Choosing the anesthetic technique varies depending on the species of the animal, the type and duration of the procedure, the experience of 
the researcher, and the purpose of the experiment (Kohn and Martin, 2007). However, intramuscular or intravenous injections and inhalation are the most commonly used methods (Moghadam et al., 2009).

Injectable anesthetics have advantages such as low cost and fast induction, and minimal equipment needs and, can be applied by intramuscular (IM), subcutaneous (SC), intravenous (IV), or intranasal (IN) routes (Vesal and Eskandari, 2006). In rabbits, IV administration is the most commonly used induction and maintenance anesthesia method, but it can be difficult to implement, and complications such as respiratory arrest may occur. On the other hand, IN application is a helpful and straightforward method that enables the drug to reach the central system directly by the olfactory and trigeminal nerves; therefore, it acts as fast as IV administration. It also does not cause pain in the application area as much as intramuscular injections (Santangelo et al., 2016a; Santangelo et al., 2016b). Due to the indication for the use of diazepam in treating of acute seizures, studies are carried out on the nasal route in terms of its practicality (Li et al., 2000; Kaur et al., 2008). There are also limited studies of intranasal administration of various ketamine combinations in rabbits. (Canpolat et al., 2016; Weiland et al., 2017). This study aimed to compare the onset, duration and recovery of anesthesia following IN administration of medetomidine-ketamine or diazepam-ketamine in New Zealand White rabbits. Intranasal administration of these combinations, it was possible to provide anesthesia in the time and depth that minor surgical procedures and clinical applications could be performed.

\section{Materials and methods}

This study was approved by Aydin Adnan Menderes University Animal Experiments Local Ethics Committee (on 23/10/2018 and numbered 2018/116). Good practices for animal experimentation conducted all the procedures.

Animals: The study material constituted of 910 months old, 12 adult New Zealand White rabbits (six male, six female) weighing 2.3-4.1 kg. The rabbits were obtained from a commercial experimental animal breeding laboratory (SYLAB). The animals were housed in individual cages $(70 \times 70 \times 45 \mathrm{~cm})$ for two weeks, acclimation to environmental conditions before starting the experiment. They have maintained a 12:12 hours light-dark cycle (lights on at 06.00 hours) in a controlled housing room, temperature $16-19{ }^{\circ} \mathrm{C}$ and humidity $50-60 \%$ conditions. Animals were fed a commercial pelleted diet and tap water ad libitum.

Study Design: At the end of the acclimation period, general clinical examinations of the animals were performed, and those without any health problems were included in the trial. Each cage was given a number. On the experiment day, the animals were assigned into two groups of six by randomly choosing a number (using a random number generator). Medetomidine $(0.2 \mathrm{mg} \mathrm{kg}$; Domitor $^{\circledR}$; Zoetis, Turkey) and ketamine (10 mg kg-1; Ketasol $^{\circledR} 10 \%$; Interhas, Turkey) were administered to group $\mathrm{MK}$, and diazepam (1.0 $\mathrm{mg} \mathrm{kg}^{-1}$; Diazem $^{\circledR}$; DEVA, Turkey) and ketamine (10 $\left.\mathrm{mg} \mathrm{kg}^{-1}\right)$ were administered to group DK.

Anesthetic agents were diluted to $0.4 \mathrm{ml} \mathrm{kg}^{-1}$ with saline and administered using an injector attached to a 24 G IV catheter without a stylet. Rabbits were restrained by wrapping a towel in a sternal position and the head and neck gently dorsoflexed by an assistant for IN instillation. Anesthetic dilution was administered by inserting the catheter through the nostril up to $1 / 4$ of its length (approximately 4-5 $\mathrm{mm}$ ).

Different investigators prepared and administered the anesthetic agent to the rabbits from the ones following reflexes during anesthesia. Reflexes such as postural reflex, pinnal (ear pinch) reflex, anterior pedal withdrawal reflex, posterior pedal withdrawal reflex, and pupillary light reflex were scored before and 5, 10, 15, 20, 25, 30, 45, and 60 minutes after anesthesia by the same investigator. A hemostatic forceps was used for pinch in all rabbits, and reflexes were classified as absent or present. The time elapsed between the loss of standing reflex and return of the standing ability for 60 seconds was recorded as the duration of the anesthesia. The time interval between the loss and return of pinnal and pedal reflexes was noted as the duration of the surgical anesthesia. The time between anesthetic agent administration and the return of all reflexes was evaluated as the total anesthesia time.

Statistical analysis: SPPS 14.01 package program (Inc., Chicago, II, USA) was used for statistical analysis of the data obtained at the end of the study. Shapiro-Wilk and Levene tests were used to evaluate the data, ensure the normal distribution and homogeneity of the variances, and perform measurements. The Independent Sample ttest analyzed reflexes because the assumptions were met. The Variance Analysis method was preferred for repeated measurements such as respiration rate, heart rate, body temperature, and SpO2. For all statistical decisions, $\mathrm{P}<0.05$ criterion was used as the level of significance. 


\section{Results}

Between the DK and MK groups; The time to loss of all reflexes such as postural reflex, pinnal reflex, tail reflex, anterior pedal reflex, posterior pedal reflex, and pupillary reflex was shorter in the DK group than MK group (Table 1, Figure 1). The mean time of onset of anesthesia was $2.1 \pm 0.2$ minutes in the DK group, but it was $6.4 \pm 1.4$ minutes in the MK group. Also, the means of recovery time of all reflexes and duration of anesthesia (second) were more extended (66 \pm 4.3 minutes) in the MK group than in the DK group (33.5 \pm 1.6 minutes) (Table 1$)$.

The respiratory rate decreased at the 5th, 10 th, 15th, 20th, 25th, 30th, 45th, and 60th minutes compared to the 0th minute in both groups in terms of the time factor. There was no difference in respiratory rate between DK and MK groups (Figure 1).

Heart rates decreased at the 45th and 60th minutes in both groups compared to the 0th minutes. However, the MK group revealed lower heart rates than the DK group ( $p=0.003$ ) (Figure 2).

There was no significant difference in body temperature in terms of group and time (Figure 3 ). However, SpO2 was decreased at the 15th, 20th and 25th minutes compared to the Oth minute in the MK group ( $p=0.010, p=0.017, p=0.015)$. Also, the MK group revealed lower values which indicates hypoxemia comparing the DK group $(p=0.019)$ (Figure 4).

Table 1. Differences between the Diazepam-Ketamine (DK) group and Medetomidine-Ketamine (MK) groups in terms of loss and recovery of all reflexes and duration of anesthesia in the rabbits $(n=6)$. Data are minutes presented as mean \pm standard deviation.

\begin{tabular}{|c|c|c|c|c|c|c|c|c|}
\hline \multirow[b]{2}{*}{ Group } & \multicolumn{6}{|c|}{ Reflexes } & \multirow{2}{*}{$\begin{array}{c}\text { Recovery } \\
\text { of all } \\
\text { Reflexes }\end{array}$} & \multirow{2}{*}{$\begin{array}{l}\text { Duration of } \\
\text { Anesthesia }\end{array}$} \\
\hline & Postural & Pinnal & Tail & $\begin{array}{c}\text { Anterior } \\
\text { Pedal }\end{array}$ & $\begin{array}{c}\text { Posterio } \\
\text { r Pedal }\end{array}$ & Pupillary & & \\
\hline D/K & $1.1 \pm 0.2$ & $2 \pm 0.1$ & $1 \pm 0.1$ & $2.2 \pm 0.2$ & $2.1 \pm 0.2$ & $2.1 \pm 0.2$ & $33.5 \pm 1.6$ & $33.5 \pm 1.6$ \\
\hline $\mathrm{M} / \mathrm{K}$ & $3.9 \pm 0.7$ & $6.4 \pm 1.4$ & $6.6 \pm 1.3$ & $6.6 \pm 1.3$ & $6.4 \pm 1.4$ & $6.4 \pm 1.4$ & $66 \pm 4.3$ & $66 \pm 4.3$ \\
\hline$p$ & 0.003 & 0.01 & 0.007 & 0.009 & 0.013 & 0.013 & $<0.001$ & $<0.001$ \\
\hline
\end{tabular}
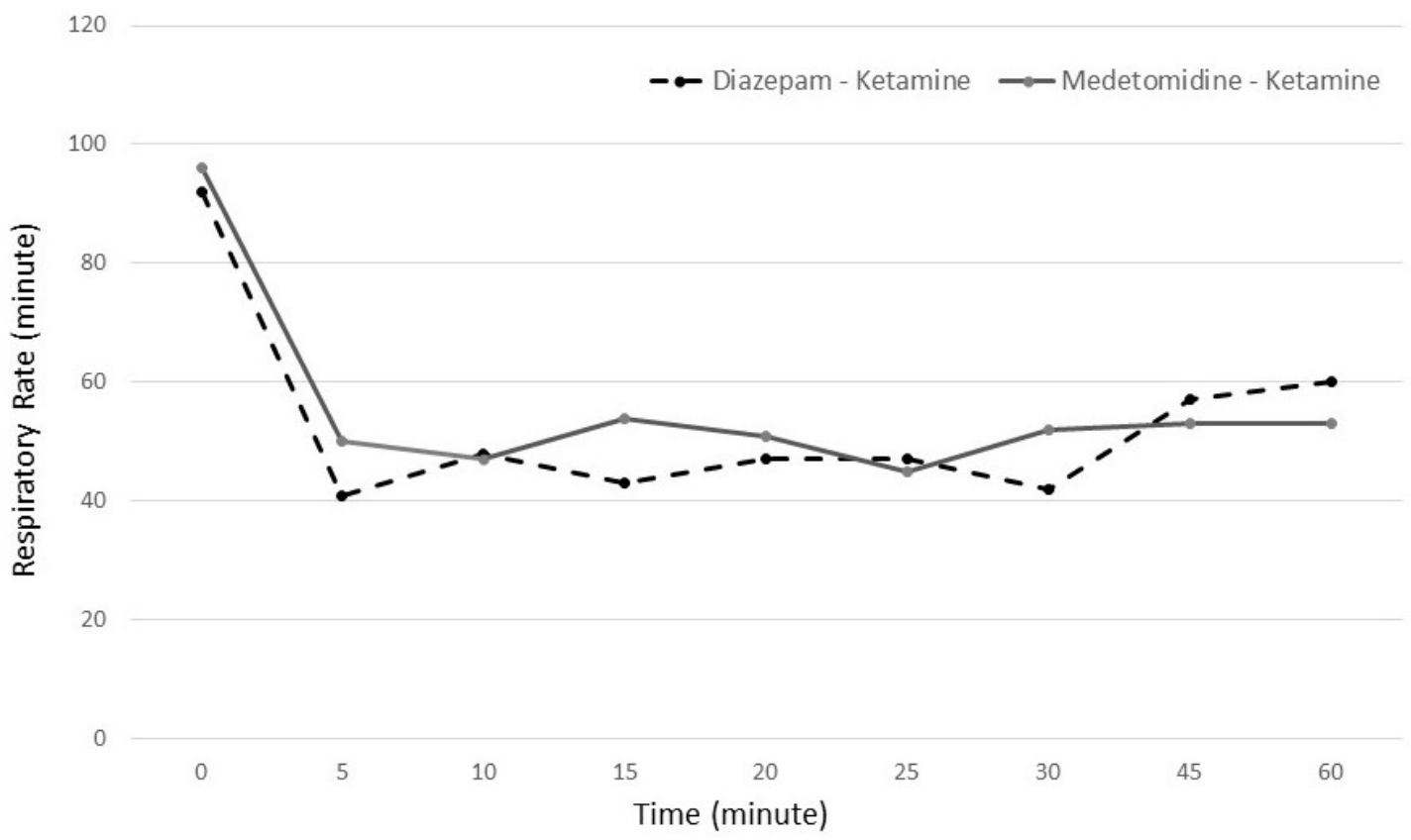

Figure 1. The changes in respiratory rate in terms of time factor $(p<0.005$ at the 5 th, 10 th, 15 th, 20th, 25th, 30 th minutes and $\mathrm{p}<0.05$ at $45 \mathrm{t}^{\mathrm{th}}$ and $60^{\text {th }}$ minutes comparing the 0 th minute). 


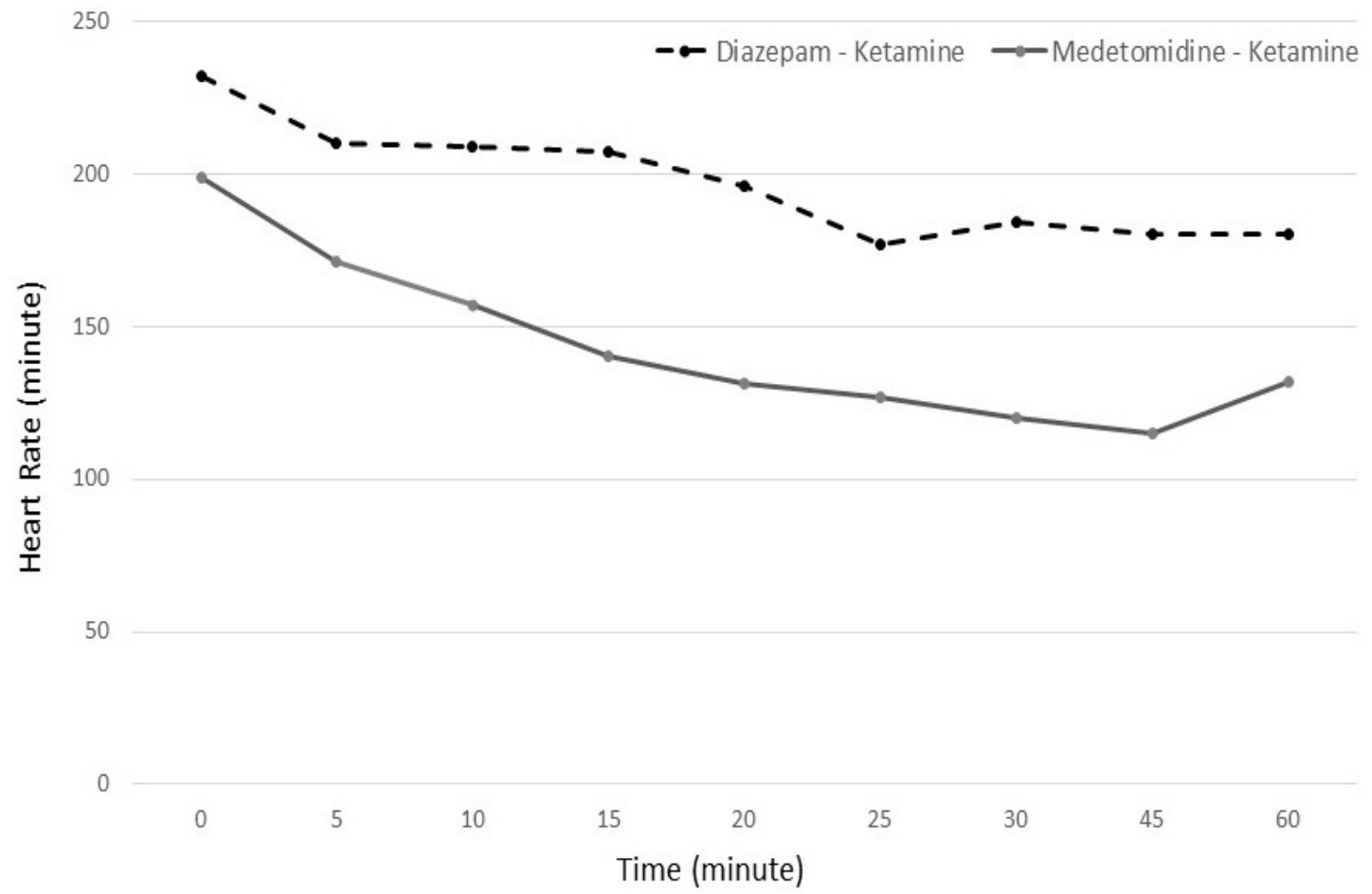

Figure 2. The changes in heart rate in terms of time factor ( $p<0.05$ at $45 t^{\text {th }}$ and 60 th minutes comparing the 0th minute) and that the heart rates of the DK group were higher than the MK group ( $p=0.003)$.

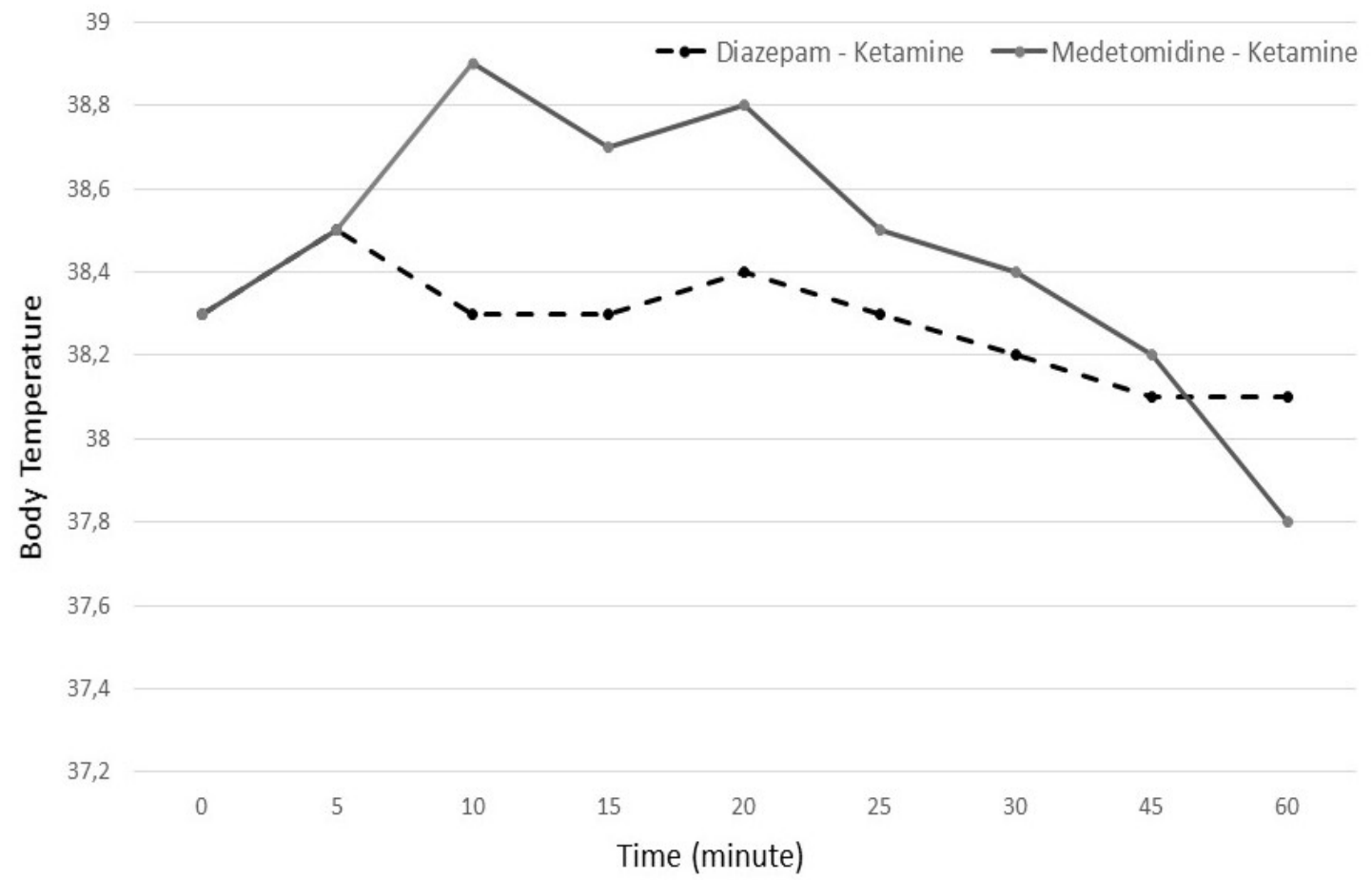

Figure 3. The changes in body temperature. No significant difference was seen between groups and in terms of time factor. 


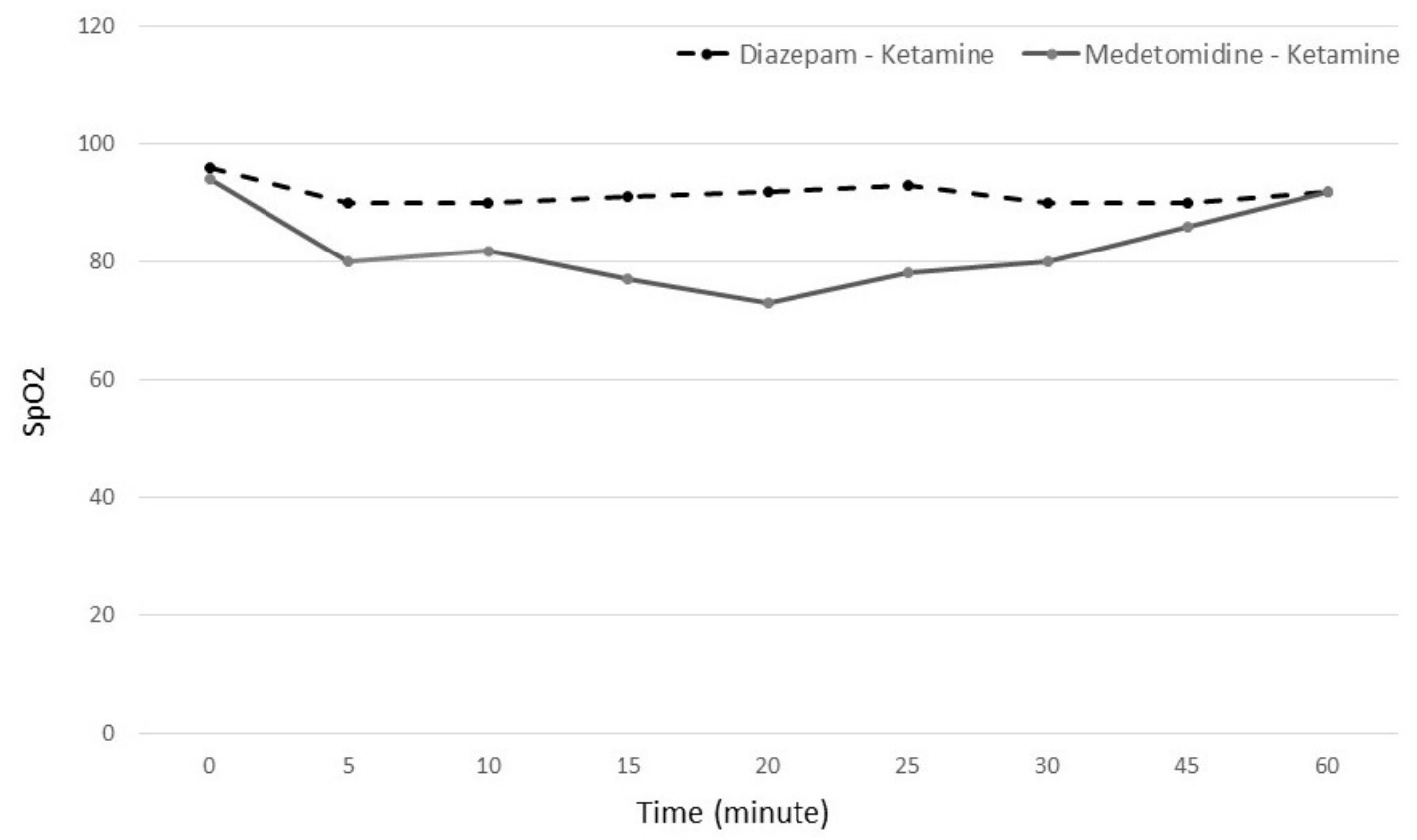

Figure 4. The changes in SpO2 in terms of group and time. SpO2 decreased in MK group at the 15 $5^{\text {th }}(p=0.010)$, $20^{\text {th }}(p=0.017)$ and 25 th $(p=0.015)$ minutes compared to the Oth minute.

\section{Discussion and Conclusion}

Rabbits are cited as the third most common animal species that take anesthesia for medical and scientific reasons. However, more deaths caused by anesthesia are reported than in dogs and cats (1.39\%) (Brodbelt, 2009). Thus, it is essential to constitute anesthetic methods and protocols that do not affect the study results and cause physiological changes or permanent damage in rabbits (Claire et al., 2005). In the presented study, all rabbits recovered from anesthesia without any problems.

Today, the most preferred anesthetics are those applied by injection and inhalation (Moghadam et al., 2009). Low cost, fast anesthesia induction, and minimal equipment requirement than to inhalation anesthesia give prominence to injectable anesthesia in practical use (Vesal and Eskandari, 2006). On the other hand, disadvantages include the inability to provide sufficient depth of anesthesia and unintentionally prolonged anesthesia duration (Rozanska, 2009). It was effortless to administer anesthesia by intranasal route during the study. Rabbits easily tolerated the procedure.

Intramuscular medetomidine - ketamine anesthesia in rabbits gives very successful results (Henke et al., 2005). Medetomidine increases the degree of visceral anesthesia and provides comfortable wakening for the animal. Therefore, it is often used with ketamine (Okumuş, 2003). Complications such as hypotension, bradycardia, respiratory depression, diuresis and, glycosuria are known to occur with additional doses (Rozanska et al., 2009). The combination of diazepam and ketamine is reported to cause minimal cardiovascular and respiratory depression besides excellent muscle relaxant effects (Gil et al., 2004). The anesthesia protocols used in the study caused an expected decrease in respiratory frequency, heart frequency, and body temperature. The decrease in $\mathrm{SpO} 2$ indicated significant hypoxemia in the MK group.

Intravenous administration of additional doses required to maintain anesthesia in rabbits causes problems such as respiratory arrest (Santangelo et al., 2016a; Santangelo et al. 2016b; Weiland et al. 2017). Intranasal administration acts as quickly as IV administration. In addition, it is a helpful and straightforward method that does not cause pain where it is performed like intramuscular applications (Santangelo et al., 2016a; Santangelo et al. 2016b). Intranasal administration of anesthetic agents alone or in combination was previously reported in rabbits (Vesal and Zare, 2006). The administration method, drug amount, and animal's position affect the absorption of the drug (Weiland et al., 2017). Both groups in this study provided a depth and duration of anesthesia in which minor surgical procedures can be performed without the need for an additional dose. 
This result indicated that the drug dose, route of administration, and position were chosen appropriately for the procedure.

In a study that investigated the plasma pharmacokinetics and brain uptake of diazepam in New Zealand white rabbits after intravenous (1 mg $\mathrm{kg}-1$ ) and intranasal administration (2 mg kg-1), it was found that diazepam was rapidly absorbed into the systemic circulation and showed readily and nearly homogeneous distribution into the brain tissues following IN and IV administration in rabbits (Kaur and Kim, 2008). In another study performed on rabbits, intranasal diazepam (1 $\left.\mathrm{mg} \mathrm{kg}^{-1}\right)$, The peak plasma concentrations were observed within 2-3 min and it was concluded that the anticonvulsants might be promptly and timely delivered to patients in need of emergency treatment for status, through the IN application ( $\mathrm{Li}$ et al., 2000). In the presented study, the dose range of IN diazepam was accepted as $1-2 \mathrm{mg} \mathrm{kg}^{-1}$ based on previous studies, and it was used as $1 \mathrm{mg} / \mathrm{kg}$ since it would be combined with ketamine.

In a study compares that the efficacy and side effects of induction with medetomidine $(0.2 \mathrm{mg} \mathrm{kg}$ $\left.{ }^{1}\right)$ ketamine $\left(10 \mathrm{mg} \mathrm{kg}^{-1}\right)$ or medetomidine $\mathrm{S}(+)$ ketamine $\left(5 \mathrm{mg} \mathrm{kg}^{-1}\right)$ by intranasal (IN) instillation in rabbits, no significant differences were reported between treatments and both procedures allowed for endotracheal intubation shortly after IN delivery (Weiland et al., 2000). Another study where ketamine was administered intranasally in combination with morphine and dexmedetomidine in rabbits reported that deep sedation was successfully provided for 20 minutes (Canpolat et al., 2016). In the presented study, successful anesthesia was induced using the combination of 10 $\mathrm{mg} \mathrm{kg}^{-1}$ ketamine with $0.2 \mathrm{mg} \mathrm{kg}^{-1}$ medetomidine.

These results showed that both MK and DK combinations administered IN provide anesthesia in the time and depth that minor surgical procedures and clinical applications could be performed. However, the onset and duration of the anesthesia were shorter in the DK group than in the MK group, and the decrease in respiratory rate, heart rate, and $\mathrm{SpO} 2$ was lower in the DK group. Although no vital complications were encountered in the presented study, $\mathrm{SpO} 2$ was severely decreased, especially in the MK group. This study has limitations, such as blood gases analysis could not be performed and has a small number of animals. Therefore, it is clear that more detailed studies with more animals are needed before routine clinical use. However, it seems promising considering its practicality and anesthetic efficacy.

\section{References}

Bechgaard E, Gizurarson S, Hjortkjaer RK, 1997: Pharmacokinetic and pharmacodynamic response after intranasal administration of diazepam to rabbits. J Pharm Pharmacol, 49, 747-750.

Brodbelt DC, 2009: Perioperative mortality in small animal anesthesia. Vet J, 182, 152-161.

Canpolat I, Karabulut E, \& Cakir S, 2016: The efficacy of intranasal administration of dexmedetomidine, ketamine and morphine combination to rabbit. Int $J$ Dev Res, 6(7), 8634-6.

Carlsson HE, Hagelin J, Hau J. 2004: Implementation of the 'Three Rs' in biomedical research. Vet Rec, 154, 467-470.

Claire A, Richardson, Paul A. et al., 2005: Anesthesia and Post-operative Analgesia Following Experimental Surgery in Laboratory Rodents: Are We Making Progress? Altern Lab Anim, 33, 119-127.

Gil AG, Silvan G, Illera M, Illera JC, 2004: The effects of anesthesia on the clinical chemistry of new zealand white rabbits. J Am Assoc Lab Anim Sci, 43, 25-29.

Henke J, Astner S, Brill T et al., 2005: Comparative study of three intramuscular anesthetic combinations (medetomidine/ketamine, medetomidine/fentanyl/ midazolam and xylazine/ketamine) in rabbits. Vet Anaesth Analg, 32, 261-270.

Kaur P, Kim K, 2008: Pharmacokinetics and brain uptake of diazepam after intravenous and intranasal administration in rats and rabbits. Int J Pharm, 364, 27-35.

Kohn DF, Martin T, 2007: Guidelines for the Assessment and Management of Pain in Rodents and Rabbits. $J$ Am Assoc Lab Anim Sci, 46, 97-108.

Li L, Gorukanti S, Choi YM, Kim KH, 2000: Rapid-onset intranasal delivery of anticonvulsants: pharmacokinetic and pharmacodynamic evaluation in rabbits. Int J Pharm, 199, 65-76.

Moghadam AZ, Sadegh AB, Sharifi S, Habibian S, 2009: Comparison of intranasal administration of diazepam, midazolam and xylazine in Pigeons: Clinical evaluation. Iran J Vet Sci Tec, 1, 19-26.

Rozanska D, 2009: Evaluation of medetomidinemidazolam-atropine (MeMiA) anesthesia maintained with propofol infusion in new zealand white rabbits. Pol J Vet Sci, 12, 209-216.

Santangelo B, Micieli F, Mozzillo T, et al., 2016a: Transnasal administration of a combination of dexmedetomidine, midazolam and butorphanol produces deep sedation in New Zealand White rabbits. Vet Anaesth Analg, 43, 209-214.

Santangelo B, Micieli F, Marino F, et al., 2016b: Plasma concentrations and sedative effects of a dexmedetomidine, midazolam, and butorphanol combination after transnasal administration in healthy rabbits. J Vet Pharmacol Ther, 39, 408-411.

Vesal N, Eskandari $\mathrm{MH}$, 2006: Sedative effects of midazolam and xylazine with or without ketamine and detomidine alone following intranasal administration in Ring-necked Parakeets. J Am Vet Med Assoc, 228, 383-388. 
Vesal N, Zare P, 2006: Clinical evaluation of intranasal benzodiazepines, a2-agonists and their antagonists in canaries. Vet Anaesth Analg, 33, 143-148

Weiland LC, Kluge K, Kutter APN, et al., 2017: Clinical evaluation of intranasal medetomidine-ketamine and medetomidine-S(+)-ketamine for induction of anesthesia in rabbits in two centres with two different administration techniques. Vet Anaesth Analg, 44, 98-105.

*Correspondance: Zeynep BOZKAN

Aydın Adnan Menderes University, Faculty of Veterinary

Medicine, Department of Surgery, Aydın/Turkey.

e-mail: zbozkan@adu.edu.tr 